Journal of Life Economics

Cilt / Volume 6, Say1 / Issue 3, 2019, pp. 239-248

E - ISSN: 2148-4139

URL: http://www.ratingacademy.com.tr/ojs/index.php/jlecon

DOİ: https://doi.org/10.15637/jlecon.6.014

Araştırma Makalesi/Research Article

\title{
DIGITAL CUSTOMER ENGAGEMENT DIMENSIONS IN DIGITAL TRANSFORMATION AND A FRAMEWORK SUGGESTION FOR RETAIL BANKING
}

\author{
Yakup AKGÜL* \& Hadi RUBACI** \\ * Dr., Kuwait Finance House / KUWAIT, \\ e-mail: yakup.akgul@kfh.com \\ ORCID ID: https://orcid.org/0000-0002-7881-3613 \\ ** Dr., Kuveyt Turk Participation Bank/TURKEY, \\ e-mail: hadi.rubaci@kuveytturk.com.tr \\ ORCID ID: https://orcid.org/0000-0003-3582-2779
}

Geliş Tarihi: 5 Mayıs 2019; Kabul Tarihi: 26 Haziran 2019

Received: 5 May 2019; Accepted: 26 June 2019

\begin{abstract}
Although there are many implications regarding customer experience, retention, loyalty etc. the comprehensive approach for digital customer engagement still needs more attention. Digital platforms leave customer alone with his or her community without bank's involvement. This approach requires a good business understanding that will match the CE network with digital capabilities. Since the customer engagement is one of the four pillars of digital transformation, retail banks should start to measure digital CE score based on each customer group as a holistic approach to cover full cycle.

Transactional customers who have low relational and emotional exchange will switch the brand easily since they have big price and satisfaction sensitivity. Delighted customers have a good commitment level but requiring interaction and relationship with the brand. Loyal customer's commitment level changes easily based on market conditions, however they have a good relationship level with the brand. Fans have good relationship and commitment level with the brand. They advocate for the brand easily.
\end{abstract}

Keywords: Customer Engagement, Digital Customer Engagement, Digital Transformation, Customer Relationship Management

JEL Codes: M15, M31, O32 


\section{INTRODUCTION}

As new technologies started to disrupt business as usual, digital transformation has gained a tremendous role nowadays. One of the most enthusiastic sectors about digital transformation is retail banking industry. Since Fintech companies, new generation payment methods started to affect banking industry, it has been a crucial fact for banks to take action for digital transformation. According to Korn Ferry's report the main areas that banks need to focus on due to Fintechs are as follows in figure 1 (Success Factors for Digital Transformation in Banks, 2018).

Figure 1: Digital Promise: Success Factors for Digital Transformation in Banks, Korn Ferry Institut, 2018

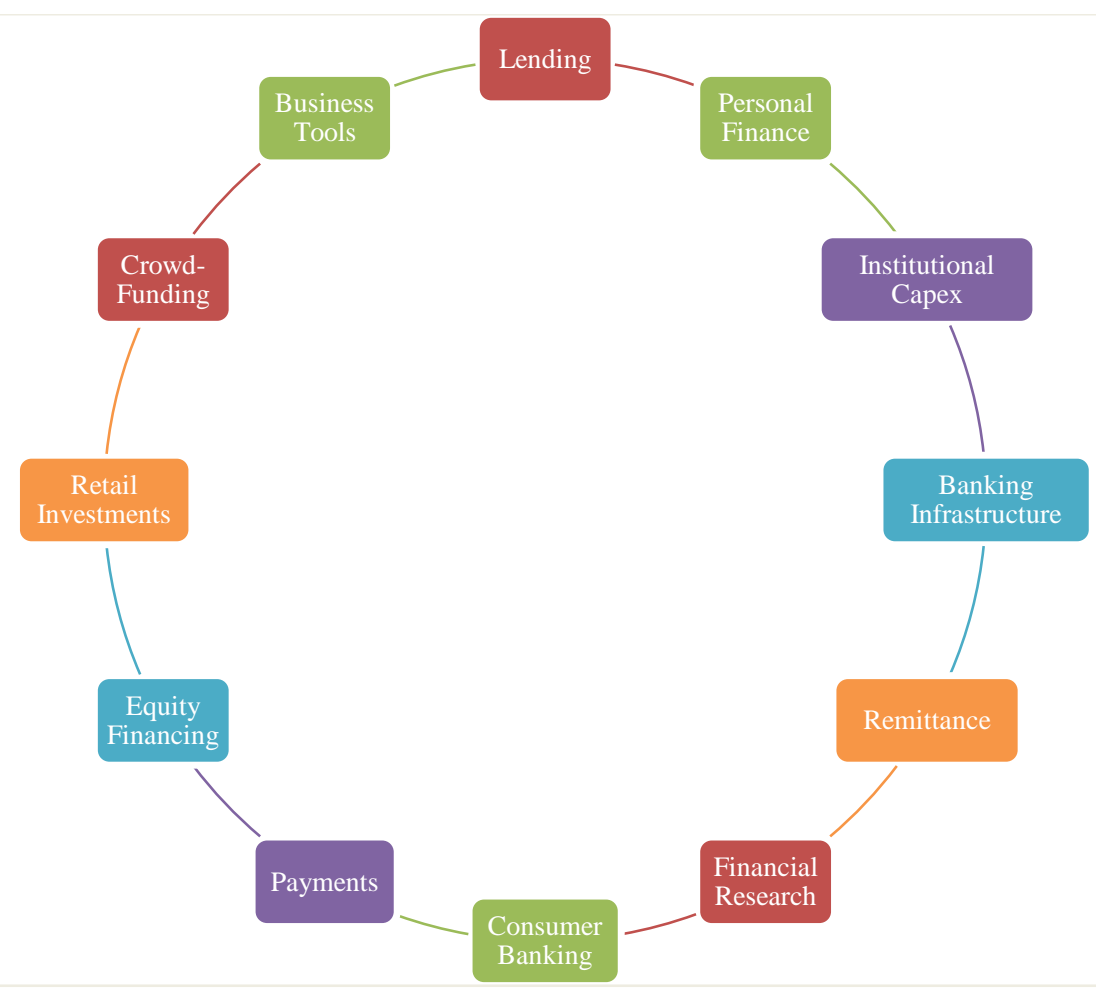

Although retail banks are fond of digital transformation, it takes time due to old technological infrastructure for full adaptation. In order to this fact banks need to determine their strategy before starting digital transformation. According to Sebastian and others main motive for digital transformation is to integrate existing business capabilities with new technologies such as SMACIT (Social, Mobile, Analytics, Cloud and IoT) and main dimensions are depicted in the figure 2 . 
Figure 2: Elements of Digital Transformation at Big Old Companies: Sebastian, I. et. Al., How Big Old Companies Navigates Digital Transformation, MIS Quarterly Executive, 2017.

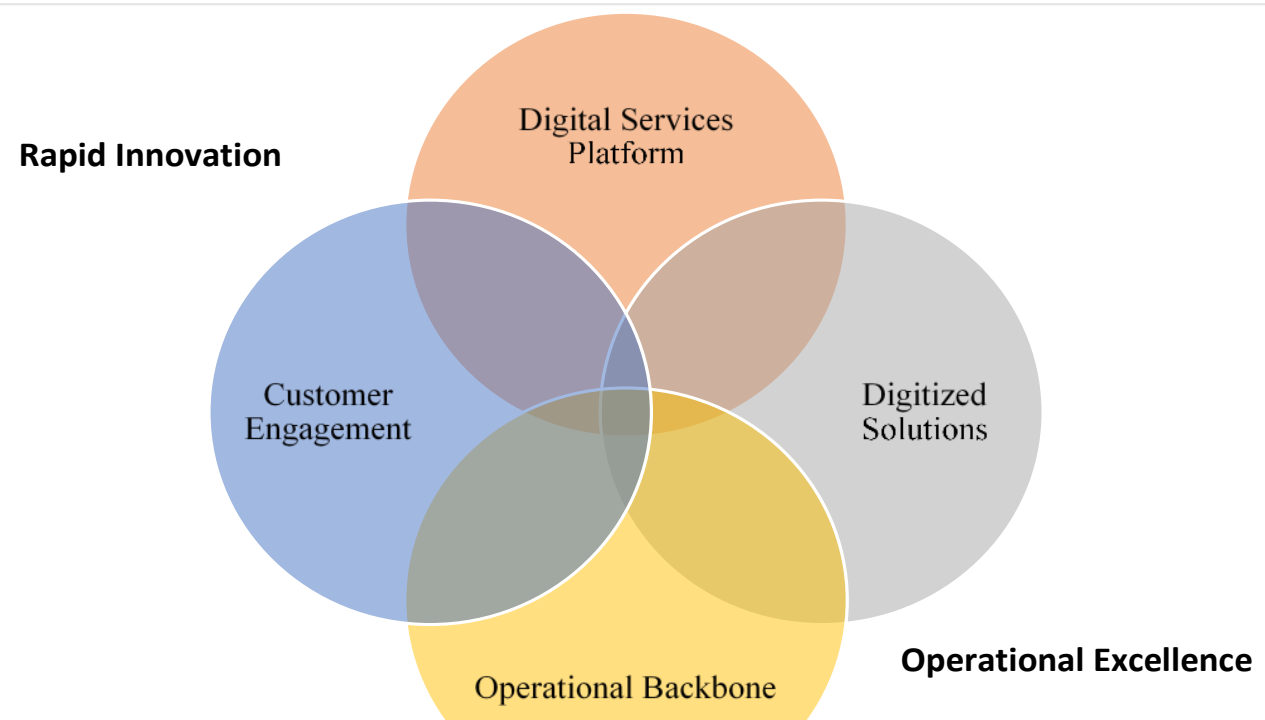

A digital strategy is required to maintain approach above. According to Sebastian and others, company leaders who wants to move ahead in digital have one of two strategies; customer engagement or digitized solutions (2017). Customer engagement strategy is mainly driven by willingness of creating loyal customers who do advocacy of the company as well. On the other hand, digitized solutions strategy is mainly driven by reformulating companies value propositions by R\&D efforts and digitized products (Sebastian, I. et.al., 2017). Since, banks are in service industry and customer satisfaction is the key success factor, this article focused on Customer Engagement (CE) dimensions in digital transformation.

\section{CUSTOMER ENGAGEMENT IN DIGITAL TRANSFORMATION}

Once, Philip Kotler introduced marketing 3.0 as new generation marketing in 2010, one of the main factors was new technological capabilities such as social media which enabled customer to be involved in companies marketing initiatives, product development etc. This new capabilities bring a new approach and enable companies to reshape their social environment as well. Besides this fact, Customer engagement notion also started to be available in the market which provides a new approach for customer satisfaction and loyalty. Seamless Omni channel Experience (Order, inquire, pay, receive support from any channel at any time), SMACIT technologies availability (Social Media, Mobile, Analytics, Cloud, IoT), reaching customer (video, text, email) capabilities are main drivers for customer experience (Sebastian, I. et. Al, 2018)

The aim of a customer engagement strategy is the development of customer loyalty and their advocacy. Companies choosing this approach offer seamless, Omni channel customer experiences, rapid responses to new customer demands, and personalized relationships built upon deep customer insights (Ross,w.j. et. Al, How to Develop a Great Digital Strategy,2017)

Brodie and others indicated multiple definitions of customer engagement which are below is available to create a common understanding of CE in digital platforms (Customer Engagement: Conceptual Domain, Fundamental Propositions, and Implications for Research, 2011). According to this approach $\mathrm{CE}$ has three dimensions which are $\mathrm{C}$ (cognitive), $\mathrm{E}(\mathrm{emotional}), \mathrm{B}$ (behavioral). The main definitions are as follows: 
- It is suggested that within interactive, dynamic business environments, customer engagement (CE) represents a strategic imperative for generating enhanced corporate performance, including sales growth, superior competitive advantage, and profitability.

- Customer engagement (CE) refers to the types of connections consumers make with other consumers, companies, and specific brands; $\mathrm{CE}$ is viewed as being conducive to enhancement of brand loyalty.

- Customer engagement includes (a) retention; (b) effort; (c) advocacy; and (d) passion

- Engagement behaviorally summarizes the impact of marketing/branding communications activities in the hearts and minds of consumers in a manner that leads to sales, margin, market share, market value, and cash flow.

- The rationale underlying these assertions is that engaged customers play a key role in viral marketing activity by providing referrals and/or recommendations for specific products, services, and/or brands to others. Engaged customers can also play an important role in new product/service development and in creating experience and value.

On the other hand, Brodie and others indicates that $\mathrm{CE}$ has five dimensions in terms of conceptual domain (2011). The conceptual dimensions of CE are proposed as;

- FP1: Psychological state which starts with interaction with a focal agent/object

- FP2: Dynamic, iterative process of service relationships which co-creates value

- FP3: Nomo logical network of service relationships

- FP4: Multidimensional aspect of CE (cognitive, emotional, behavioral) interactions which aroused from set of situational conditional with different complexity levels

- FP5: Different CE levels as result of different situational conditions.

The 5 conceptual dimensions above also can be summarized as the cycle below in figure 3 which will result in different CE levels. Levels of CE is usually categorized as; fully engaged, engaged, disengaged, and actively disengaged.

Figure 3: Customer Engagement Cycle

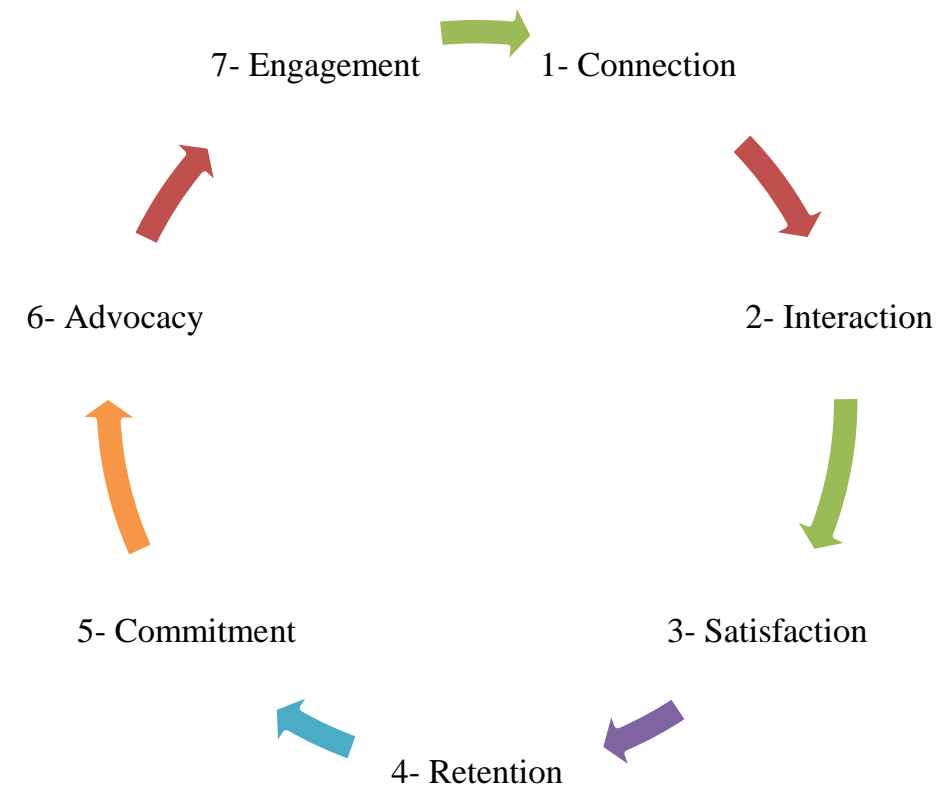


As it is shown above, key factors such as customer satisfaction, customer retention(loyalty) are only mediators for a final outcome to get engaged customers. For example, satisfaction does not always mean loyalty. After retention the commitment of customers which mean that customer who have emotional attachment with the company, is needed to create fans. Finally, the engagement will occur based on four levels (fully engaged, engaged, disengaged, and actively disengaged). Customer engagement is also can be shown in a matrix approach which is frequently used for employee engagement surveys. According to Sashi, the engagement matrix is as follows (2012) in table 1.

Table 1: Customer Engagement Matrix: Sashi, C.M. 2012, Customer engagement, buyerseller relationships, and social media

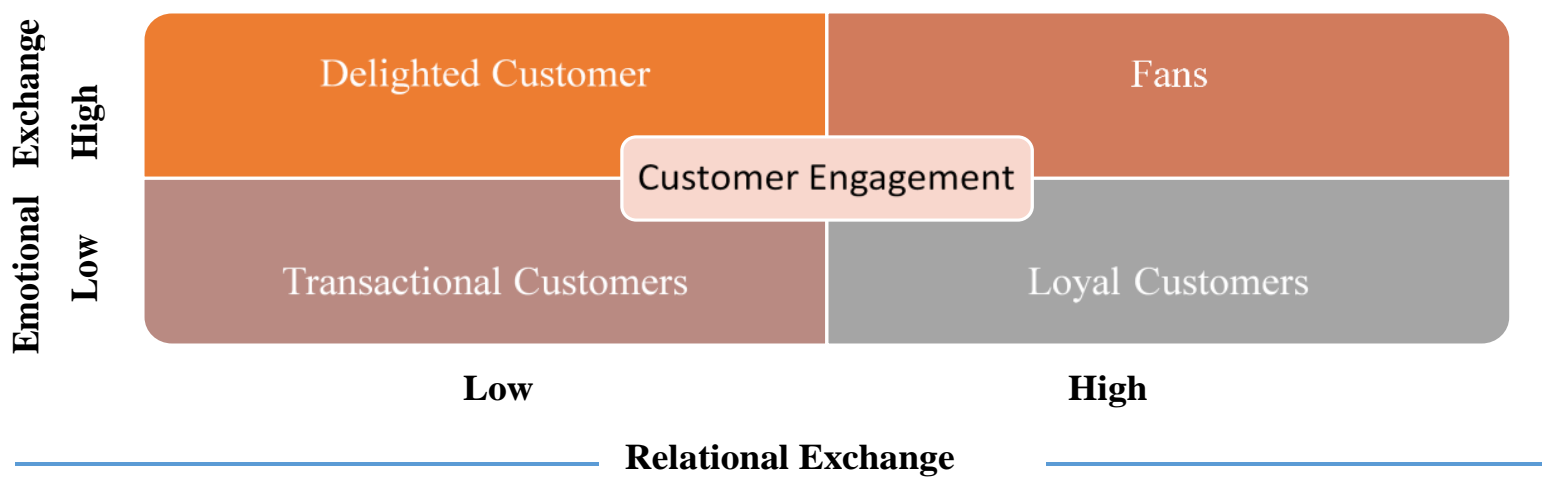

The measurement of engagement matrix has been studied by couple of studies. Three dimensions which are $\mathrm{C}$ (cognitive), $\mathrm{E}$ (emotional), $\mathrm{B}$ (behavioral) are mainly put to the scale to measure customer engagement. Hollebeek and others developed a scale based on cognitive processing, affection and activation (Consumer Brand Engagement in Social Media: Conceptualization, Scale Development and Validation,2013). Cognitive can be clarified as giving full attention to the brand to learn everything and being curious about it. Emotional can also be summarized as positive relationship with brand and to which extent customer loves the brand. On the other hand, behavioral dimension is about taking action for brand and spending his/her energy to interact with brand in any platform.

As a result, transactional customers who have low relational and emotional exchange will switch the brand easily since they have big price and satisfaction sensitivity. Delighted customers have a good commitment level but requiring interaction and relationship with the brand. Loyal customer's commitment level changes easily based on market conditions, however they have a good relationship level with the brand. Fans have good relationship and commitment level with the brand. They advocate for the brand easily.

\section{A FRAMEWORK SUGGESTION FOR RETAIL BANKING APPLICATION}

This research examined main dimensions of customer engagement cycles interrelated with digital capabilities among different industries. A mix of digital capabilities that will make sure that customer will be able to bounce from one stage to another with available tools is needed for retail banking. It is assuming that different maturity levels for seven stages in $\mathrm{CE}$ cycle leads to different CE Level and is resulted with a CE Matrix. Hence, the research can be regarded as gap analysis for $\mathrm{CE}$ dimensions in terms of customer perceptions and enable future researches to apply statistical models. As per the gap analysis approach, three dimensions and engagement cycle components merged in a matrix. The matrix can be seen below in table 2 . 
Table 2: Digital Customer Engagement Dimensions and Engagement Cycle Framework

\begin{tabular}{|c|c|c|c|c|c|c|}
\hline & Connection & Interaction & Satisfaction & Retention & Commitment & Advocacy \\
\hline ن & $\begin{array}{l}\text { Enough } \\
\text { available } \\
\text { information to } \\
\text { connect with } \\
\text { the bank. }\end{array}$ & $\begin{array}{l}\text { Encouraging } \\
\text { customer to be } \\
\text { informed about } \\
\text { next steps and } \\
\text { flow }\end{array}$ & $\begin{array}{l}\text { Transactional } \\
\text { satisfaction } \\
\text { level for each } \\
\text { flow }\end{array}$ & $\begin{array}{l}\text { Intent to } \\
\text { repurchase } \\
\text { the product } \\
\text { and reuse } \\
\text { same flow }\end{array}$ & $\begin{array}{l}\text { Desire to } \\
\text { maintain } \\
\text { curiosity about } \\
\text { the bank and } \\
\text { new offers }\end{array}$ & $\begin{array}{l}\text { Inform his/her } \\
\text { connections } \\
\text { about } \\
\text { bank activities } \\
\text { positively }\end{array}$ \\
\hline 预 & $\begin{array}{l}\text { First response } \\
\text { with an } \\
\text { emotional } \\
\text { attachment }\end{array}$ & $\begin{array}{l}\text { The relationship } \\
\text { types between } \\
\text { the bank and } \\
\text { customer based } \\
\text { on each } \\
\text { situational } \\
\text { interactions }\end{array}$ & $\begin{array}{l}\text { Overall } \\
\text { satisfaction } \\
\text { between of the } \\
\text { customer } \\
\text { about the bank }\end{array}$ & $\begin{array}{l}\text { Intent to } \\
\text { maintain } \\
\text { relationship } \\
\text { with the bank } \\
\text { in digital } \\
\text { platforms }\end{array}$ & $\begin{array}{l}\text { Desire to } \\
\text { communicate } \\
\text { with the bank }\end{array}$ & $\begin{array}{l}\text { An affective } \\
\text { commitment } \\
\text { level to create } \\
\text { WOM as a fan }\end{array}$ \\
\hline טֶ: & $\begin{array}{l}\text { A connection } \\
\text { that will } \\
\text { conclude with } \\
\text { an successful } \\
\text { purchase }\end{array}$ & $\begin{array}{l}\text { Available } \\
\text { channels to } \\
\text { increase } \\
\text { customer } \\
\text { participation in } \\
\text { the flow }\end{array}$ & $\begin{array}{l}\text { Purchase } \\
\text { Satisfaction of } \\
\text { the customer }\end{array}$ & $\begin{array}{l}\text { A } \\
\text { nomological } \\
\text { network of } \\
\text { digital } \\
\text { premises that } \\
\text { enable } \\
\text { customer to } \\
\text { participate } \\
\text { more }\end{array}$ & $\begin{array}{l}\text { Desire to } \\
\text { participate the } \\
\text { bank offers } \\
\text { anytime/anyw } \\
\text { here }\end{array}$ & $\begin{array}{l}\text { An affective } \\
\text { commitment } \\
\text { level to lead } \\
\text { action for } \\
\text { his/her } \\
\text { community } \\
\text { and enable } \\
\text { them to } \\
\text { participate } \\
\text { bank offers }\end{array}$ \\
\hline
\end{tabular}

Digital platforms which are available for the banks were taken as reference and offline platforms such as branches were excluded in this approach. After defining each customer engagement cycle match with engagement dimensions, digital evaluation matrix can be done with specific activities to measure based on four engagement levels for 18 cells above.

One of the most important terms in this context is also Social CRM which is revealed with help of new technologies. Social CRM is defined as 'a philosophy and a business strategy, supported by a technology platform, business rules, processes and social characteristics, designed to engage the customer in a collaborative conversation in order to provide mutually beneficial value in a trusted and transparent business environment' (Greenberg, 2010). Social $\mathrm{CRM}$ is the enabler for advocacy and commitment due to need for interaction regarding digital customer engagement.

The service management literature argues that customer satisfaction is the result of a customer's perception of the value received in a transaction or relationship - where value equals perceived service quality relative to price and customer acquisition costs (Hallowell, 1996). The satisfaction can be considered as enabler for retention and customer loyalty due to its transactional aspect. On the other hand, retention is mainly about tenure that customer works with the company. In terms of loyalty perspective, it can be understood that as long as customer buys services and products from the company the retention will be ensured.

Commitment level is divided into two subcategories which are affective commitment and calculative commitment (Bompolis and Boutsouki, 2014). Calculative commitment is usually resulted from rational, economic benefits, however affective commitment is mainly created by personal involvement and reciprocity that the customer has with the company. 
According to Bompolis et al. affective commitment has more positive affect on CRM activities success and customer engagement compared to calculative commitment (2014).

According to Menon and O'connor word of mouth or positive advocacy is a particularly important and desired outcome of CRM for retail banks because banking is a high credence service and represents significant amount of risk and involvement for the customer (2007). A good affective commitment level implies also a positive advocacy regarding banks services and will definitely generate new businesses. A positive or negative advocacy can reach to thousands of potential or existing customers in digital platforms easily. So, it cannot be regarded as traditional word of mouth which has limited influence capacity compared to digital advocacy.

\subsection{Digital Platform Availabilities as per the CE Dimensions and Cycle Matrix}

Although there are available digital channels such as Online banking mobile applications, social media, and call centers that serve customers the new technologies also can be regarded as enablers to complete CE cycle. A few of those technologies can be seen below(Newton,2018):

A digital wallet consumer hub; allows its users to control and manage a portfolio of digital wallet functionalities, including the ability to manage digital wallets across multiple providers. It also offers analytics and enhanced account management capabilities for payment, money and secure credentials as well as loyalty. It allows to view transactions across multiple digital/mobile wallets. Provide an aggregated stream of payment transactions across all payment cards and accounts in order to support money management tools and applications.

The Internet of Things (IoT); enables business value creation by reducing operational costs, better managing risk or developing new revenue streams via digital business models and advancing technologies. The IOT in Banking relates to the collection and analysis of data generated from "things" - autonomous machines and sensors - to enhance decision making and risk management and the transformation of banking products and services as IoT becomes more integrated into the financial services demand and supply chains.

Geolocation-based products and services; integrate the physical location of customers into the core product or service proposition to deliver to them enhanced or differentiated products or services from banks and financial services companies. Specifically excluded are stand-alone location services such as ATM and branch-finder applications, which can be found in many mobile banking applications and geolocation solutions for fraud management purposes.

Wearable banking applications; enable customers to perform tasks from an electronic device worn on or attached to the body (for example, a smartwatch). Tasks include receiving alerts, taking actions based on alerts, tracking spending activity, locating ATMs and other bank facilities, performing a transaction or making a payment. Wearables include sensors and embedded intelligence (for example, microcontrollers), and can provide data wirelessly to other devices and back-office systems.

Mobile wireless payment systems (for non-mature payment markets):

Enable the initiation of transactions via mobile handsets and their authorizations through wireless networks. Funding can be via mobile phone bills, prepaid accounts, bank accounts, cards or any other type of account holding value.

Biometric mobile banking authentication; biometric mobile banking authentication describes the use of biometric technology to authenticate customers accessing mobile banking or payment applications on smartphones and tablets. It includes solutions that use technologies integrated by the technology providers like Apple and Samsung in their smartphones and 
tablets, as well face, voice and other modes implemented in software. It specially excludes use of biometrics to access ATMs and branch services.

Biometric authentication methods; biometric authentication methods use unique biological or behavioral traits to corroborate users' identities when they access endpoint devices; networks; or mobile, networked or web applications.

Open Banking; for consumers, open banking changes will mean customers have a holistic view of all their financial behavior for the first time, making it easier to manage and control their finances. New apps can collate and analyze data for people, providing them with the know-how of when and where cutting back on expenses is needed. Being able to pay through single-clicks and contactless cards means it is otherwise hard for consumers to keep on top of spending.

Robotic Process Automation; unnecessary gaps in bank processes, like "swivel-chair integration" (rekeying data from one system to another), complex and time-consuming documentation requirements, and manual decision making, disrupt the customer journey. They make it slow and confusing, and increase the likelihood of losing the customer to a more agile competitor. This problem impacts not only current customers, but also potential new customers.

- Loan applicants who get stuck in an endless loop - waiting for service, loss of documentation, resubmission and then more waiting - quickly get fed up and move on.

- New customers who experience a clunky account opening process all too often end up never bothering to fund the account (Sturgill and Tornbohm, 2018).

\section{CONCLUSION AND MANAGERIAL IMPLICATIONS}

This research aimed to suggest a framework to measure digital customer engagement with a full cycle. Although there are many implications regarding customer experience, retention, loyalty etc. the comprehensive approach for customer engagement still needs more attention. A comprehensive operational backbone is also required to manage the overall cycle for retail banks such as CRM tools. It was stated that, CRM has begun to mature in the minds of the business world as a crucial strategic tool for maintaining relationships with customers and improving front line staff performance. The e-CRM that finds application in e-commerce and $\mathrm{m}-\mathrm{CRM}$ that takes advantage of Mobile Devices (Smartphones, Tablets) to avoid losing customers and business opportunities due to lack of direct and efficient service, reveals the penetration of the CRM philosophy in every facet of business (Bompolis and Bousouki, 2014).

This study mainly contemplates about young generations changing preferences due to new social and communication channels. According to Tesfom and Birch, young and older bank customers significantly differ in their perception of relational benefits, switching costs, availability and attractiveness of alternatives, service recovery and the duration of time they intend to end their relationship (retention) with their banks, furthermore younger customers are more likely to identify better alternative attractive benefits offered by other competing banks than older customers (2011). With help of digital interactions young customer can easily be affected by other bank offers and interactions. Hence, although traditional customers are impressed by tangible assets such as ATMs, branch comfort, relationship manager attitude etc. the new generation is also impressed by intangible dimensions such as social interactions and offers. The advocacy and commitment levels are more related with this dimension since they are resulted from affective reciprocal digital interactions and personal involvement than transactional measurements. A positive or negative advocacy can reach to thousands of potential or existing customers in digital platforms easily. So, it cannot be regarded as traditional word of mouth which is limited compared to digital advocacy. As a summary, a very 
comprehensive CRM strategy and digital presence and measurement is required for retail banks to manage the change.

This approach requires a good business understanding that will match the CE network with digital capabilities. Since the customer engagement is one of the four pillars of digital transformation, companies should start to measure digital CE score based on each customer group as a holistic approach to cover full cycle. This study makes it clear that, however they are interrelated Digital CE measurement is different from measuring customer satisfaction level or Net Promoting Score due to its main components. The study suggests to build this measurement specifically for digital transformation to create a clear roadmap and investment plan for future customers. 


\section{REFERENCES}

BOMPOLIS, C.G.; BOUTSOUKI, C. (2014), Customer Relationship Management in the Era of Social Web and Social Customer: An Investigation of Customer Engagement in the Greek Retail Banking Sector, Procedia - Social and Behavioral Sciences (148), 67 - 78.

BRODIE, J. R.; HOLEBEEK, L. D. and JURİC, B. (2011), Customer Engagement: Conceptual Domain, Fundamental Propositions, and Implications for Research, Journal of Service Research,252-271.

GREENBERG, P. (2010). CRM at the Speed of Light: Social CRM Strategies, Tools, and Techniques for Engaging Your Customers,4th Edition, McGraw Hill, New York.

HALLOWELL, R. (1996), The Relationships of Customer Satisfaction, Customer Loyalty, and Profitability: An Empirical Study, International Journal of Service Industry Management, 7(4), 27-42.

HO, J.; CHOWDHURY, S. and EVANS, N. (2018), Success Factors for Digital Transformation in Banks, Korn Ferry Institut.

Holeebek, Consumer Brand Engagement in Social Media: Conceptualization, Scale Development and Validation,2013

KOTLER, F.; KARTAJAYA, H. and SETIAWAN, I. (2010), Marketing 3.0: From Customers to Human Spirit, John Wiley \& Sons.

MENON, K. and O'CONNOR, A. (2007), Building Customers' Affective Commitment Toward Retail Banks: The Role of CRM in Each 'Moment of Truth', Journal of Financial Services Marketing, 12(2), 157-168.

NEWTON, A. (2018). Hype Cycle for Digital Banking Transformation, 248 gartner.com/en/documents/3884070.

ROSS, W.J. ; SEBASTIAN, I.M and BEATH, M.J. (2017), How to Develop a Great Digital Strategy, MIT Sloan Management Review, 58 (2) , 7-9.

SASHI, C.M. (2012), Customer Engagement, Buyer-Seller Relationships, and Social Media, Management Decision, 50 (2), 253-272.

SEBASTIAN, I.M.; MOCKER, M.; ROSS, J.W.; MOLONEY, K. G.; BEATH, C.and FONSTAD, N.O. (2017), How Big Old Companies Navigates Digital Transformation, MIS Quarterly Executive, 16(3), 197-213.

STURGILL, N. and TORNBOHM, C. (2018). How Bank CIOs Can Use Robotic Process Automation to Improve Customer Experience, gartner.com.

TESFOM, G. and BIRCH, N.F. (2011), Do switching barriers in the retail banking industry influence bank customers in different age groups differently? Eastern Washington University, Bellevue, Washington, USA. 